\title{
Gambaran Pasien Tuberkulosis Paru Usia Produktif di RSUP Prof. Dr. R. D. Kandou Manado Periode Tahun 2014-2015
}

\author{
${ }^{1}$ Johanes F. N. Kesek, ${ }^{2}$ Cerelia E. C. Sugeng, ${ }^{2}$ Efata B. I. Polii \\ ${ }^{1}$ Program Studi Pendidikan Dokter Fakultas Kedokteran Universitas Sam Ratulangi Manado \\ ${ }^{2}$ Bagian Ilmu Penyakit Dalam Fakultas Kedokteran Universitas Sam Ratulangi Manado \\ Email: joelkesek@gmail.com
}

\begin{abstract}
Pulmonary tuberculosis (pulmonary TB) is caused by Mycobacterium tuberculosis, an acid-fast bacillus (AFB). This disease is characterized by pulmonary infiltrates and caseous granuloma formation, fibrosis, as well as cavities. To date, this disease is still a global health problem. The highest incidence of pulmonary TB is usually in productive age between 15 and 44 years. This study was aimed to obtain the profile of pulmonary tuberculosis patients in productive age at RSUP Prof. Dr. R. D. Kandou Manado during years 2014 to 2015. This was a descriptive observational study using data of medical records. The result showed that there were 178 pulmonary TB patients in the age group of 15-44 years. Based on sex, there were 94 males (52.8\%) and 84 females (47.2\%). TB patients with positive acid-fast bacilli (AFB) in sputum were found in 117 patients (65.7\%) and those with negative AFB in 61 patients (34.3\%). In conclusion, pulmonary TB patients at productive age (15-44 years) were predominant in males with positive sputum of Mycobacterium tuberculosis.
\end{abstract}

Keyword: pulmonary tuberculosis, productive age

\begin{abstract}
Abstrak: Tuberkulosis (TB) paru adalah infeksi paru yang disebabkan oleh Mycobacterium tuberculosis, yaitu sejenis basil tahan asam (BTA). Penyakit ini ditandai oleh adanya infiltrat paru dan pembentukan granuloma kaseosa, fibrosis, dan kavitas. Penyakit TB paru masih merupakan masalah global dengan insidensi tertinggi biasanya mengenai usia produktif, antara 15-44 tahun. Penelitian ini bertujuan untuk mengetahui gambaran pasien tuberkulosis paru usia produktif di RSUP Prof. Dr. R. D. Kandou Manado periode tahun 2014-2015. Jenis penelitian ialah deskriptif observasional menggunakan data rekam medis. Hasil penelitian mendapatkan 178 pasien TB paru pada golongan usia 15-44 tahun. Berdasarkan jenis kelamin didapatkan 94 orang laki-laki (52,8\%) dan 84 orang perempuan (47,2\%). Pasien TB dengan hasil pemeriksaan sputum BTA (+) sebanyak 117 orang $(65,7 \%)$ dan pasien dengan hasil pemeriksaan sputum BTA (-) sebanyak 61 orang (34,3\%). Simpulan penelitian ini ialah penderita TB paru pada usia produktif (15-44 tahun) lebih sering didapatkan pada jenis kelamin laki-laki dan dengan hasil pemeriksaan sputum BTA (+).
\end{abstract}

Kata kunci: tuberkulosis paru, usia produktif

\section{PENDAHULUAN}

Tuberkulosis (TB) paru adalah infeksi paru yang ditandai oleh adanya infiltrat paru serta pembentukan granuloma kaseosa, fibrosis, dan kavitas. Tuberkulosis dapat disebabkan akibat pajanan terhadap basil tahan asam Mycobacterium tuberculosis. ${ }^{1,2}$

Tuberkulosis masih menjadi masalah utama kesehatan global dan penyebab kematian tersering oleh infeksi setelah human immunodeficiency virus (HIV). Berdasarkan laporan World Health Organization (WHO) pada tahun 2013 prevalensi kasus TB di seluruh dunia menunjukkan terdapat hampir 9 juta kasus TB dan 1,5 juta kematian akibat TB. Di Indonesia setiap tahun ditemukan 582.000 penderita baru TB dengan angka kematian 
$41 / 100.000$ penduduk. $^{3}$ Insidens tertinggi TB paru biasanya mengenai usia produktif, antara 15-44 tahun. ${ }^{4}$ Sekitar 95\% penderita TB paru berada di negara berkembang; 75\% di antaranya ialah usia produktif.

Alasan utama TB masih menjadi masalah kesehatan global antara lain disebabkan oleh kemiskinan pada berbagai penduduk; adanya perubahan demografik dengan meningkatnya penduduk dunia dan perubahan dari struktur usia manusia yang hidup; perlindungan kesehatan yang kurang memadai di negara-negara berkembang; rendahnya pengetahuan tentang penyakit TB; terlantar dan kurangnya biaya dari pasien untuk berobat; dan adanya epidemik HIV terutama di Asia dan Afrika. ${ }^{4-6}$ Berdasarkan latar belakang ini maka penulis tertarik untuk mengetahui gambaran pasien tuberkulosis paru usia produktif di RSUP Prof. Dr. R. D. Kandou Manado periode tahun 2014-2015.

\section{METODE PENELITIAN}

Penelitian ini dilakukan di Bagian Ilmu Penyakit Dalam RSUP Prof. Dr. R. D. Kandou Manado sejak bulan Juli 2014 sampai Juni 2015 dengan menggunakan data rekam medik. Jennis penelitian ialah deskriptif observasional.

Seluruh pasien di Bagian Ilmu Penyakit Dalam RSUP Prof. Dr. R. D. Kandou Manado periode Juli 2014 sampai Juni 2015 menjadi populasi penelitian dan seluruh pasien TB paru yang berusia 15-44 tahun dengan data pemeriksaan dan perawatan yang lengkap merupakan sampel penelitian. Variabel peneliti meliputi jenis kelamin, usia pasien, dan pemeriksaan sputum BTA pasien.

Data yang dikumpulkan meliputi: nama, nomor rekam medik, usia, jenis kelamin, pemeriksaan penunjang sputum BTA pada pasien dengan TB paru berusia 15-44 tahun yang diambil dari rekam medik di Bagian Ilmu Penyakit Dalam RSUP Prof. Dr. R. D. Kandou Manado periode tahun Juli 2014 - Juni 2015.

\section{HASIL PENELITIAN}

Selama periode Juli 2014 sampai Juni
2015 didapatkan 178 pasien TB Paru usia produktif (15-44 tahun) yang memenuhi kriteria inklusi maupun kriteria eksklusi. Dari seluruh sampel, didapatkan 94 orang laki-laki (52,8\%) dan 84 orang perempuan (47,2\%) (Gambar 1). Jangkauan usia ialah 18-40 tahun (rerata 27,2 tahun, median 27 tahun, dan simpang baku 6,77).

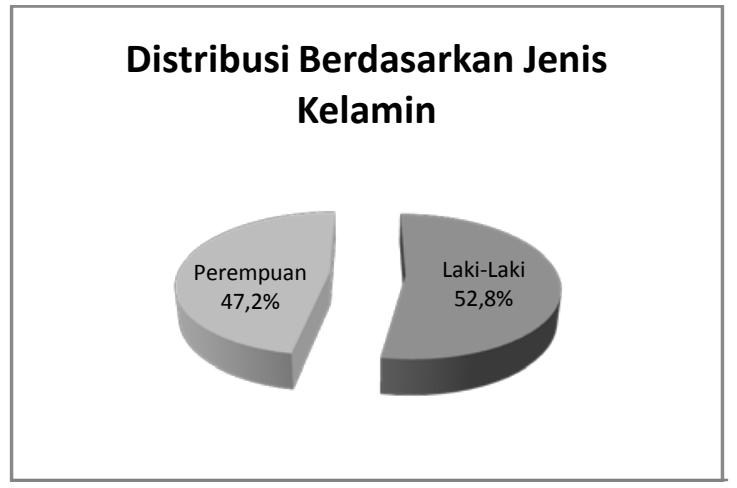

Gambar 1. Distribusi pasien berdasarkan jenis kelamin

Distribusi pasien berdasarkan pemeriksaan Sputum Basil Tahan Asam (BTA) memperlihatkan pasien TB paru dengan hasil pemeriksaan BTA (+) sebanyak 117 orang $(65,7 \%)$ dan pasien dengan hasil pemeriksaan BTA (-) sebanyak 61 orang (34,3\%) (Gambar 2).

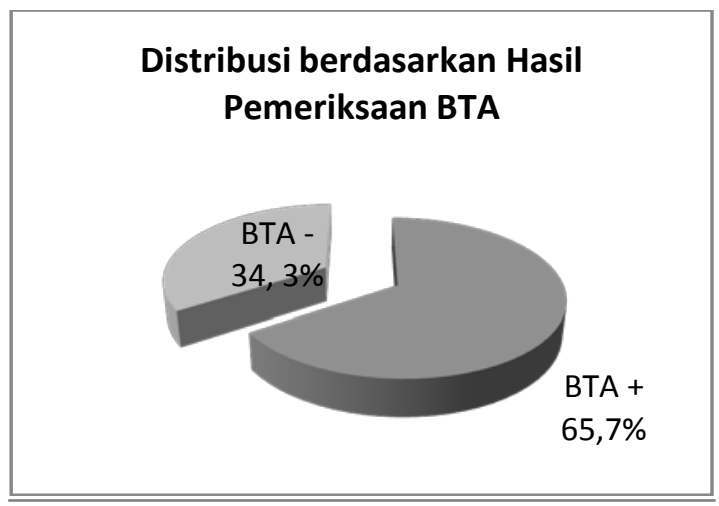

Gambar 2. Distribusi pasien berdasarkan hasil pemeriksaan sputum BTA

\section{BAHASAN}

Penelitian ini dilakukan di Bagian Ilmu Penyakit Dalam RSUP Prof. Dr. R. D. Kandou Manado dengan menggunakan data rekam medik periode Juli 2014 sampai dengan Juni 2015. Jumlah sampel pasien TB paru pada usia produktif sebanyak 178 
orang. Dari 178 sampel ditemukan pasien dengan jenis kelamin laki-laki sebanyak 94 orang $(52,8 \%)$ dan pasien dengan jenis kelamin perempuan sebanyak 84 orang (47,2\%). Sampel yang diambil pada penelitian ini berusia antara 15-44 tahun dengan usia rerata 27 tahun. Hasil penelitian ini sejalan dengan penelitian sebelumnya yang dilakukan oleh Pertiwi et $\mathrm{al}^{7}$ yang menggunakan sampel sebanyak 30 orang yang berada pada golongan usia 1555 tahun (76,7\%). Pertiwi el $\mathrm{al}^{7}$ melaporkan bahwa jenis kelamin laki-laki lebih banyak daripada perempuan. Penelitian serupa yang dilakukan oleh Sitohang et $\mathrm{al}^{8}$ melaporkan bahwa dari 58 sampel penelitian, didapatkan sebayak 33 pasien yang menderita TB paru berjenis kelamin laki-laki, dengan golongan usia terbanyak pada usia 15-49 tahun.

Hasil penelitian ini mendapatkan bahwa pasien dengan hasil pemerikasaan BTA $(+)$ lebih banyak dari pada pasien dengan hasil pemeriksaan BTA (-) (Gambar 2). Hal ini selaras dengan penelitian yang dilakukan Sihotang et $\mathrm{al}^{8}$ yang juga mendapatkan pasien dengan hasil pemeriksaan BTA (+) lebih banyak daripada pasien dengan hasil pemeriksaan BTA (-). Temuan ini menunjukkan bahwa pasien dengan hasil pemeriksaan BTA (+) cenderung lebih banyak daripada pasien dengan hasil pemeriksaan BTA (-), yang berdampak buruk terhadap penularan penyakit ini. Selain itu, hasil penelitian ini menunjukkan bahwa risiko terkena TB di usia 15-44 tahun lebih tinggi pada jenis kelamin lakilaki.

\section{SIMPULAN}

Berdasarkan hasil penelitian ini dapat disimpulkan bahwa penderita TB paru usia produktif (15-44 tahun) lebih sering didapatkan pada jenis kelamin laki-laki dan dengan hasil pemeriksaan sputum BTA $(+)$.

\section{DAFTAR PUSTAKA}

1. Saputra L. Organ System: Visual Nursing Respiratorik (1st ed). Tangerang: Binarupa Aksara, 2014; p. 97.

2. Amin Z, Bahar A. Tuberkulosis Paru. In: Sudoyo AW, Setiyohadi B, Alwi I, Simadibrata M, Setiadi S, editors. Ilmu Penyakit Dalam (4th ed). Jakarta Pusat: Interna Publishing, 2009: p. 2230-9.

3. World Health Organization (WHO). Global Tuberculosis Report 2014. 2014 Aug [cited 2015 Sep 25].

4. Perkumpulan Pemberantasan Tuberkulosis Indonesia (PPTI). Hubungan dukungan sosial dengan kualitas hidup pada penderita tuberkulosis paru (Tb Paru) di Balai Pengobatan Penyakit Paru (Bp4) Yogyakarta Unit Minggiran, 2012

5. Puspitasari P, Wongkar MCP, Surachmanto E. Profil pasien tuberkulosis paru di Poliklinik Paru RSUP Prof. Dr. R. D. Kandou Manado. e-CliniC. 2014;2(1).

6. Amin Z, Bahar A. Pengobatan tuberkulosis mutahir. In: Sudoyo AW, Setiyohadi B, Alwi I, Simadibrata M, Setiadi S, editors. Ilmu Penyakit Dalam (4th ed). Jakarta Pusat: Interna Publishing, 2009; p. 2240-8.

7. Pertiwi RN, Wuryanto MA, Sutiningsih D. Hubungan antara karakteristik individu, praktik hygiene dan sanitasi lingkungan dengan kejadian tuberculosis di Kecamatan Semarang Utara Tahun 2011. Jurnal Kesehatan Masyarakat. 2012; 1(2):435-45.

8. Sihotang H, Lampus B, Pandelaki A. Gambaran penderita tuberkulosis paru yang berobat menggunakan DOTS Di Puskesmas Bahu Malalayang I periode Januari-Desember 2012. Jurnal Kedokteran Komunitas dan Tropik. 2013; 1(1):68-72. 